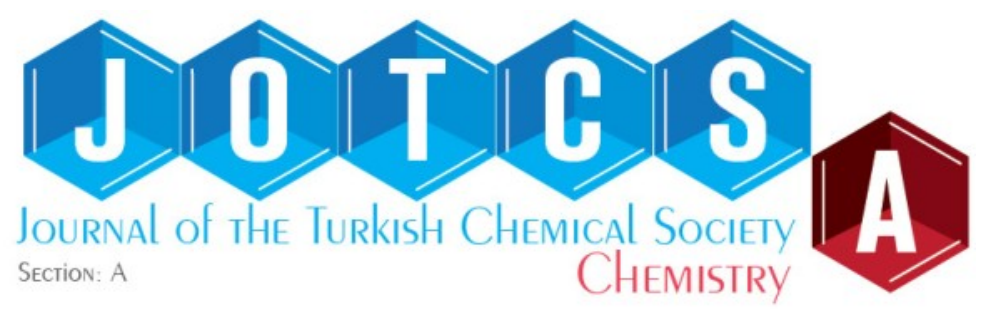

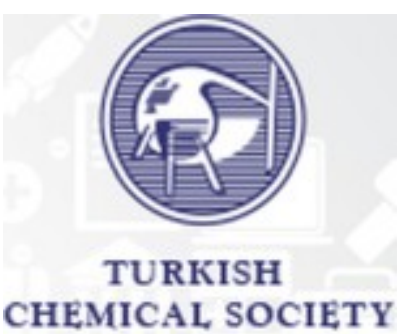

\title{
Usage of Cellulose Acetate Butyrate Based Oligomeric Structures on Cotton Fabric Coatings
}

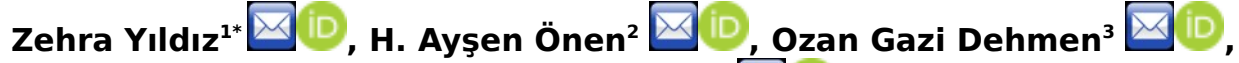 \\ and Atilla Güngör ${ }^{4}$ D \\ ${ }^{1}$ Marmara University, Faculty of Technology, Department of Textile Engineering, Kadıköy, İstanbul, 34722, \\ Türkiye \\ ${ }^{2}$ Istanbul Technical University, Faculty of Science and Letters, Department of Chemistry, Maslak, İstanbul, \\ 34467, Türkiye \\ ${ }^{3}$ Istanbul Technical University, Institute of Science and Technology, Polymer Science and Technology, Maslak, \\ İstanbul, 34467, Türkiye \\ ${ }^{4}$ Marmara University, Faculty of Science and Letters, Department of Chemistry, Kadıköy, İstanbul, 34722,
} Türkiye

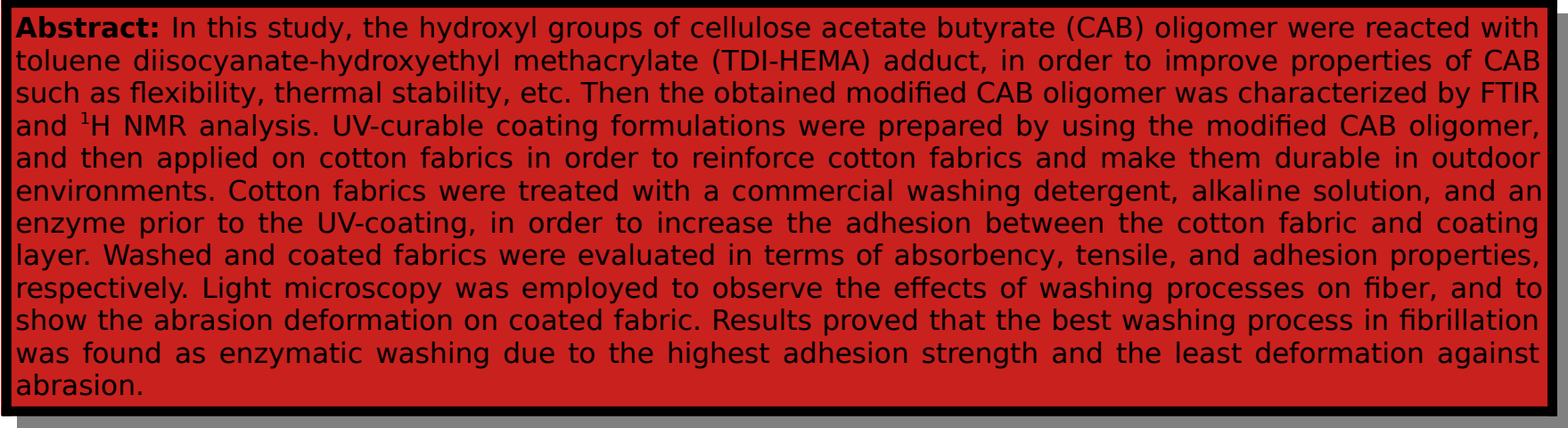

Keywords: UV-Curing; Cellulose Acetate Butyrate; Cotton Fabric; Pectinase Enzyme; Peel Test.

Submitted: October 20, 2019. Accepted: January 09, 2021.

Cite this: Yıldız Z, Önen HA, Dehmen OG, Güngör A. Usage of Cellulose Acetate Butyrate Based Oligomeric Structures on Cotton Fabric Coatings. JOTCSA. 2021;8(1):303-10.

DOI: https://doi.org/10.18596/jotcsa.634996.

*Corresponding author. E-mail: zehra.yildiz@marmara.edu.tr.

\section{INTRODUCTION}

Cellulose is a biopolymer that is the most abundant, easily accessible, and cheap raw material and is widely used in many commercial applications. The hydroxyl groups of cellulose allow its conversion into regenerated cellulose via the formation of ester and ethers by the reaction with various chemical species. This modification process gives the desired physical/chemical properties that are required for the usage area. The most important commercially available cellulose ester derivatives are as follows; cellulose acetate, cellulose acetate propionate and butyrate, and carboxymethyl cellulose acetate butyrate. Among all cellulose derivatives, cellulose acetate butyrate $(C A B)$ has some superior properties such as high scratch resistance and being economical. The inelastic rod-like structure of $C A B$ crystals causes a high viscosity of $C A B$ in a molten state that restricts the processability of CAB. Besides, the low thermal stability of polysaccharide structures of $C A B$, leads to a narrow processability range between the melting and decomposition temperatures, thus lowers the thermal stability of $C A B$. In order to overcome the mentioned problems, some researches based on the modification of $C A B$ 
have been performed but there is no research considering the modification of the $C A B$ by using the urethane-based oligomers (1-3).

UV-curing technology is favored due to the requirement of less solvent or none (environment friendly), processability at low temperatures (economical), and saving of time with a rapid crosslinking mechanism just in a few seconds (mass production). UV-curable coatings can be used as varnishes, adhesives, inks, functional coating materials in many industries such as automotive, printing, dentistry, furniture, micro-electronics, biomedical, optical, and packaging products. The reaction of toluene diisocyanate-hydroxyethyl methacrylate (TDI-HEMA) is often performed in literature, to prepare UV- sensitive coating formulations. Here, the UV-curable acrylate groups are provided by HEMA, which supplies the usage of solvent/waste-free process and provides time and cost-efficiency. Whereas the isocyanate groups of TDI gives an elastic behavior to the oligomer due to the formation of carbamate ester units. In TDI-HEMA reaction, some isocyanate functional groups are left unreacted intentionally in order to give additional functionalities by introducing other active species in further reactions. For instance, TDI-HEMAfunctionalized carbon nanotubes, TDI-HEMA-epoxy acrylate oligomers, TDI-HEMA-butyl acrylate oligomers have all been manufactured via the usage of TDI-HEMA adduct in the literature (4-9).

Due to the hydrophobic impurities on cotton fibers such as waxes, pectin, grease, hemicellulose, protein etc., the solution uptake and wettability properties of fibers negatively affected during the finishing processes. Therefore, cotton fibers need to be scoured in order to enhance the hydrophilicity and dyestuff uptake, to improve the compatibility between fiber/finishing agent, and to increase the adhesion strength between the fiber/coating layer. In this study, a commercial washing process with standard ECE washing powder, alkali treatment with concentrated sodium hydroxide $(\mathrm{NaOH})$ solution, and enzymatic washing with pectinase enzyme were all employed for cotton fabric scouring. The ECE washing powder is a non-ionic, phosphated, without optical brightening agent and used in textile fastness tests. It helps to remove the water/detergent soluble impurities from the fiber surface. In alkali treatment, concentrated $\mathrm{NaOH}$ solution helps to dissolve the impurities such as lignin, hemicellulose, grease, and waxes on the fiber surface. During the alkaline treatment, the surface area of fibers increases due to the fibrillation which supplies a better penetration of the coating layer. The enzymatic washing step presents, some advantages over the other washing steps such as being sustainable and eco-friendly, requiring less energy, and giving less deformation to the fiber surface. Pectinase enzyme was chosen to decompose the pectinic impurities on cotton fabric. In literature, PET fabrics have been treated with cutinase enzyme and $\mathrm{NaOH}$ solution, respectively. Accordingly, the enzymatic washing process showed a better performance in the fibrillation of PET fabric compared to the alkaline treatment (10-18).

In this study, the hydroxyl groups on $C A B$ structure were modified by TDI-HEMA adduct in order to enhance the undesired properties of $C A B$. Then the modified $C A B$ oligomers obtained were included in UV-curable coating formulations on cotton fabrics. In order to improve the adhesion between the cotton fiber and coating layer, fabrics were treated with an alkaline solution, pectinase enzyme, and ECE washing powder, respectively. The abrasion, tensile, and adhesion properties of washed and coated fabrics were all investigated.

\section{EXPERIMENTAL}

\section{Materials}

CAB (Eastman 551-0.01, 53 \% wt. butyryl, $2 \%$ wt. acetyl, $1.5 \%$ wt. hydroxyl content), 1.6-hexanediol diacrylate (HDDA, Merck, reactive diluent), tetrahydrofuran (THF, Merck), toluene diisocyanate (TDI, Merck), 2-hydroxyethyl methacrylate (HEMA, Merck), sodium hydroxide ( $\mathrm{NaOH}$, Merck), dibutyltin dilaurate (DBTDL, T12 catalyst, Merck), 1hydroxycyclohexyl phenyl ketone (Irgacure ${ }^{\circledR} 184$, photo initiator, Ciba Specialty Chemicals), non-ionic wetting agent (Uniwett HGA Alfa Kimya), ECE phosphated, without optical brightening agent (SDL Atlas) were all used as received. Cotton fabrics (115 $\mathrm{g} / \mathrm{m}^{2}, 30$ warp/cm, 22 weft $/ \mathrm{cm}$ ) were obtained from Tavsanlı Tekstil Co.

\section{Preparation and Application of Coating Formulations}

Figure 1 shows the synthesis steps of TDI-HEMA modified $C A B$ oligomer. Firstly, TDI-HEMA in an equimolar ratio, HDDA (30\% wt.), T12 catalyst, and THF were all loaded to a round bottomed flask, under nitrogen atmosphere, equipped with a condenser and magnetic stirrer. THF and HDDA were used to dissipate a sudden temperature increase and to dilute the reaction media, respectively. The reaction was performed for the first half an hour in an ice bath, another half an hour at $25^{\circ} \mathrm{C}$, then $1 \mathrm{~h}$ at $70^{\circ} \mathrm{C}$. The decrease in the intensity of isocyanate peak was followed by FTIR spectroscopy during the reaction. In the second step, certain amounts of $C A B$, allowing to react only $50 \%$ of hydroxyl groups on it, was dissolved in THF and included into the reaction flask. The temperature was raised to $90{ }^{\circ} \mathrm{C}$ and ended in half an hour by checking the disappearance of isocyanate peak in FTIR spectra. The rest of the hydroxyl groups on $C A B$ were intentionally left unreacted in order to give flexibility to the oligomer. Due to the differences in reactivity of isocyanates in para and ortho positions, at first isocyanates in para position react with the hydroxyl groups of HEMA, whereas the isocyanates in ortho position reacts with the hydroxyl groups of $C A B$ in the second step, at a higher temperature. 


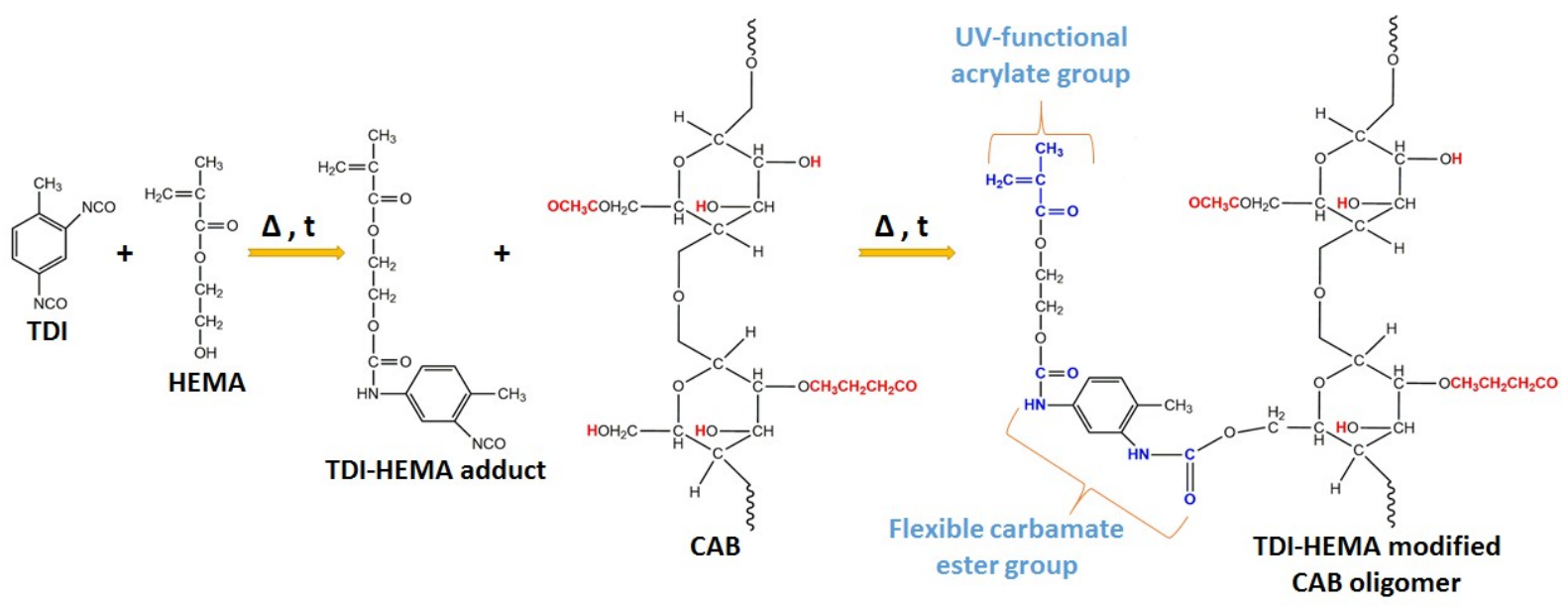

Figure 1. Synthesis of TDI-HEMA modified CAB oligomer.

Cotton fabrics were cut in $15 \times 20 \mathrm{~cm}$ dimensions that are needed to make the T-peel test. The process parameters of each washing processes can be seen in Figure 2. The washing processes were all performed on an enclosed Pyrex glass with $25 \mathrm{~cm}$ diameter, equipped with a magnetic stirrer. Fabrics were immersed in the washing media and were laid out on the bottom of Pyrex. Distilled water was used on each rinsing step.

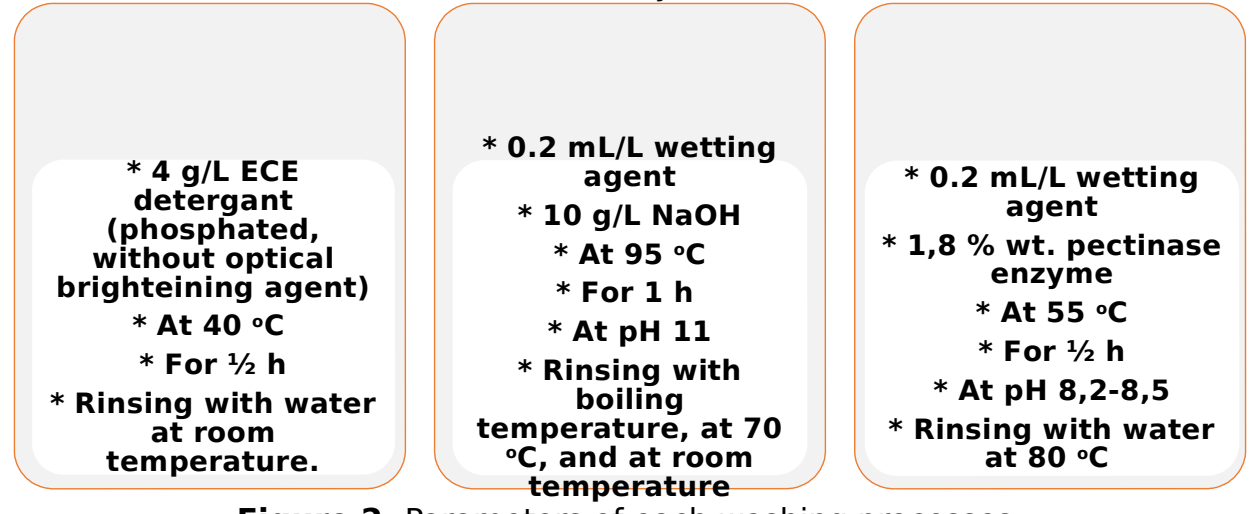

Figure 2. Parameters of each washing processes.

Fabric samples with various washing processes were dipped into the coating formulation containing 3\% wt. photoinitiator for $3 \mathrm{~min}$. After that fabrics were put between two PE films and pressed by a squeezing roller to dissipate the excess resin from the fabric. Then fabrics were exposed to UV-light for
$3 \mathrm{~min}$ from both sides of the fabric between two glass plates. The fabric coating process was performed in both one layer and two layers of fabric in order to make the tensile testing and T-peel test, respectively. Figure 3 illustrates the fabric coating and curing processes.

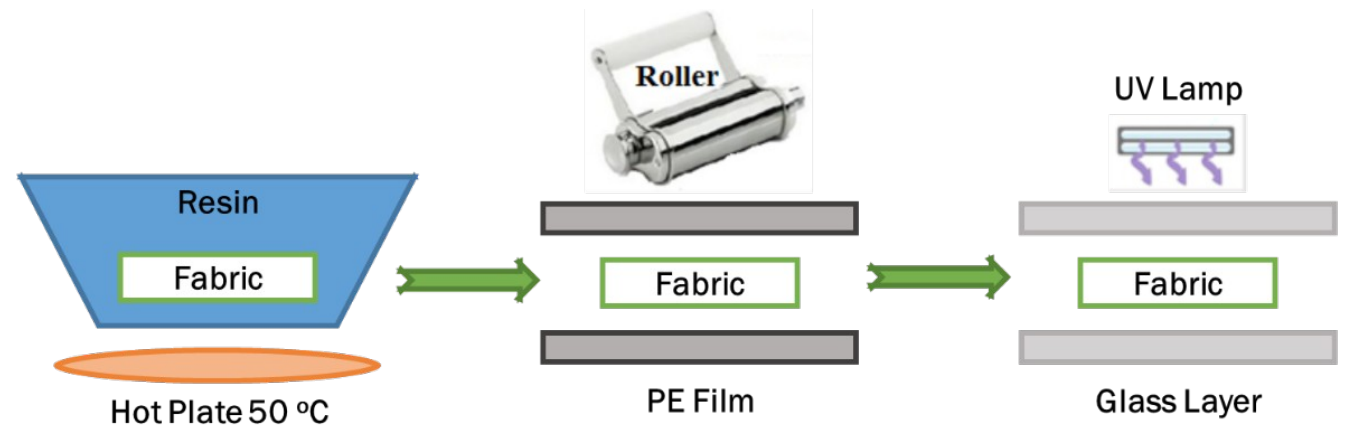

Figure 3. Application of coating formulations and UV-curing.

\section{Characterization}

The synthesized TDI-HEMA adduct and modified CAB oligomer were characterized by FTIR (Perkin Elmer Spectrum 100 FTIR equipped with a ZnSe ATR 
crystal) and ${ }^{1} \mathrm{H}$ NMR spectroscopic methods (Agilent VNMRS $500 \mathrm{MHz}$, with deuterated dimethylsulfoxide (DMSO- $d_{6}$ ) as solvent and tetramethylsilane (TMS) as an internal standard). In order to evaluate the hydrophilicity property of fabrics after washing steps, an absorbency test (AATCC-79-2004) was employed (19). Tensile testing (TS EN ISO 13934-1) (20) and abrasion test (TS EN ISO 12947-2 for fabrics without coating layer, TS EN ISO 5470-2 for fabrics with coating layer) $(21,22)$ were performed in Instron 4411 tensile testing machine, and Martindale pilling and abrasion instrument, respectively. The adhesion strength in double layered coated fabrics was measured by the T-peel test (ASTM D1876-08) also in Instron 4411 tensile testing machine (23).

\section{RESULTS AND DISCUSSION}

\section{FTIR Analysis}

The FTIR spectra of TDI-HEMA adduct and modified $C A B$ oligomers can be seen in Figure 4. Accordingly, in the spectra of TDI-HEMA adduct, the isocyanate peak at $2270 \mathrm{~cm}^{-1}$ disappeared with the reaction of CAB. This result can be explained by the reactivity differences of isocyanate groups. Due to the steric hindrance of methyl groups, the isocyanate groups of TDI in ortho-position are four times less reactive than the isocyanate groups in para-position. Thus in the first step, the isocyanates in para-position react with the hydroxyl groups of HEMA. Whereas the isocyanates in ortho-position react with the hydroxyl groups of $C A B$ in the second step due to the increased temperature. The characteristic HEMA peaks of $\mathrm{C}=\mathrm{C},=\mathrm{CH}_{2}$, and $=\mathrm{CH}$ were observed at $1635 \mathrm{~cm}^{-1}, 1450 \mathrm{~cm}^{-1}$, and $810 \mathrm{~cm}^{-1}$, respectively. The characteristic carbamate ester peaks of $\mathrm{N}-\mathrm{H}$ bending and $\mathrm{C}=\mathrm{O}$ stretching were observed at 1529 $\mathrm{cm}^{-1}$ and $1732 \mathrm{~cm}^{-1}$ in the spectra of modified CAB oligomer (24-26).

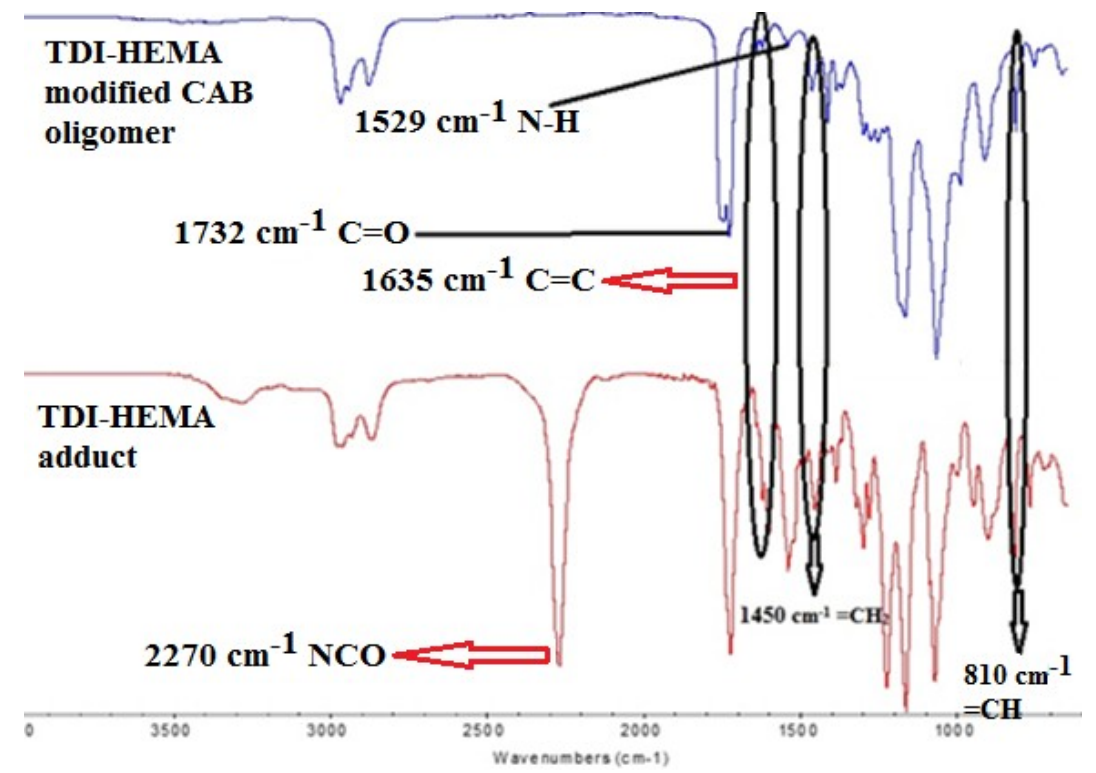

Figure 4. FTIR spectra of TDI-HEMA adduct and modified CAB oligomers.

\section{${ }^{1}$ H NMR Spectra}

The ${ }^{1} \mathrm{H}$ NMR spectra of TDI-HEMA modified CAB oligomer was given in Figure 5 . The characteristic methacrylic proton peaks of HEMA can be followed from the peaks at 4.27-4.35 ppm (-O- $\left.\mathrm{CH}_{2}-\mathrm{CH}_{2}-\mathrm{O}\right)$, at

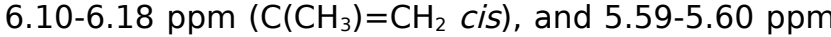
$\left(\mathrm{C}\left(\mathrm{CH}_{3}\right)=\mathrm{CH}_{2}\right.$ trans $)$, respectively. At 2.14-2.17 ppm region, the methyl proton peak of TDI can be observed. The existence of carbamate ester groups $(-\mathrm{NH}-\mathrm{COO})$ in the structure can be seen with the proton peak at $5.01 \mathrm{ppm}$. The proton peaks of the cellulose structure can be all observed at 3.32-4.18 ppm region $(25,27-29)$. 


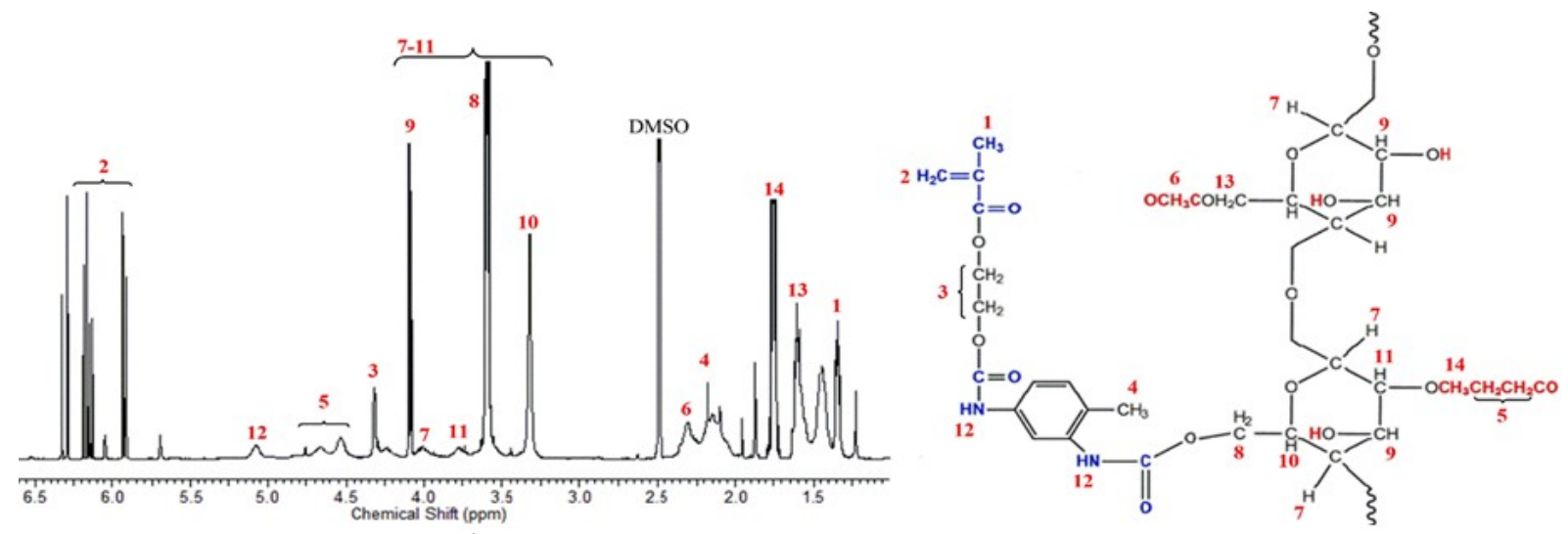

Figure 5. ${ }^{1} \mathrm{H}$ NMR spectra of TDI-HEMA modified CAB oligomer.

\section{Absorbency Test}

The hydrophilicity behavior of fabrics after various washing processes was investigated by using an absorbency test according to the AATCC TM79-2018 standard (19). The absorbency test is performed by following a complete disappearance of a distilled water droplet, which is dripped from a certain height, on the fabric surface, by using a chronometer. Accordingly, the absorbency test value of 142 seconds was recorded on the unwashed fabric surface. After washing processes, the absorbency test result was recorded as 3 seconds for each washing procedure. When the fabric was coated with the UV-curable formulation, the absorbency test result was obtained as more than 24 hours, which means the water droplet cannot be immersed into the fabric surface. The decline on the absorbency test results from the 142 seconds to the 3 seconds after washing is due to the fibrillation of fibres. Fibrillation causes a rougher look (Figure 6) and the formation of more surface area among fiber structure which means more points are formed to bond the liquid on the fabric surface.

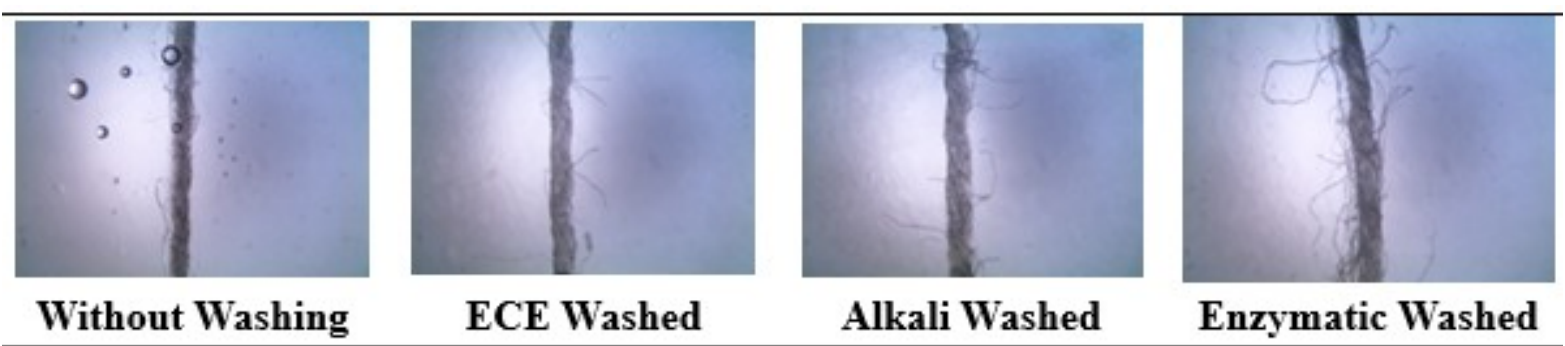

Figure 6. Light microscopy images of single fiber from the fabric without washing and fabrics after each washing processes.

\section{Abrasion Resistance Test}

The abrasion resistance values of pure fabric, fabrics after washing, and fabrics after UV-coating with their light microscopy images were all given in Table 1. The abrasion resistance test for uncoated washed fabrics was recorded according to the TS EN ISO 13934-1 standard. Fabrics were cut in $5 \mathrm{~cm}$ diameter and allowed to be abraded towards a standard wool fabric. When a yarn was a break in both warp and weft directions, the test is ended. Results are given in terms of "cycle". Pure cotton fabric showed a 38,000 cycle before damaged. The smooth surfaces are more durable against abrasion than corresponding rough surfaces. After washing steps, due to the fibrillation on fiber surface, fabrics gained a rougher look, thus the abrasion resistance values were all decreased. It was recorded as 34,000 cycle (ECE washed), 32,000 cycle (alkaline-washed), and 30,000 cycle (enzymatically washed), respectively.
After UV-coating process, another abrasion test which is suitable for resin coated fabrics were performed according to the TS EN ISO 5470-2 standard. On this test, coated fabrics were cut into 5 $\mathrm{cm}$ diameter and allowed to be abraded by a sandpaper. The evaluation was made in terms of the weight loss percentage after 100 cycle abrasion. Accordingly, after UV-coating process, the unwashed fabric showed a $20.3 \%$ weight loss in abrasion test. Whereas when the fabrics are washed prior to the UV-coating process, the abrasion results were all decreased. And the least weight loss value of $11.6 \%$ was recorded in the case of enzymatically washed UV-coated fabric sample. This result is due to the highest fibrillation level of enzymatic washing, resulting a better bonding between the fiber surface and the coating layer. The light microscopy images of UV-coated fabrics after 100 cycle abrasion were also supported this result. 
Table 1. Abrasion resistance values of fabrics before/after washing and UV-coating

\begin{tabular}{|c|c|c|c|c|c|}
\hline 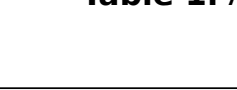 & $\begin{array}{l}\text { Without } \\
\text { Washing }\end{array}$ & ECE-Washed & $\begin{array}{l}\text { Alkaline- } \\
\text { Washed }\end{array}$ & $\begin{array}{c}\text { Enzymatically } \\
\text { Washed }\end{array}$ & \\
\hline $\begin{array}{c}\text { Abrasion } \\
\text { Resistance } \\
\text { (cycle) }\end{array}$ & 38,000 & 34,000 & 32,000 & 30,000 & 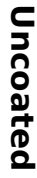 \\
\hline $\begin{array}{c}\text { Abrasion } \\
\text { Resistance } \\
\text { (weight loss, } \\
\%)\end{array}$ & 20.3 & Microscopy & After A & n Test & $\begin{array}{l}2 \\
0 \\
0 \\
0 \\
0 \\
0\end{array}$ \\
\hline
\end{tabular}

\section{Tensile and Peel Testing}

Table 2 shows the tensile strength values of pure fabric and fabrics after each washing processes. Also the peel strength values of double layered UVcoated fabrics were given in Table 2 . An increase in tensile strength values were observed due to the fibrillation after washing processes. This result is stemming from the increase in surface roughness with fibrillation, more adherence points are formed on the fiber surfaces (Figure 6). Thus fabrics become more durable after washing. The highest tensile strength value of $1080 \mathrm{~N}$ was recorded on the sample with pectinase enzyme washing. Considering the peel testing results, as in tensile testing, due to the increase in surface roughness the adherence between the coating layer and fiber surface increases. Thus the highest peel test value of $27.8 \mathrm{~N}$ was also recorded in the sample with enzymatic washing. Figure 7 illustrates the possible bonding mechanism between the UV-coating layer and cotton fabric surface. The strong hydrogen bondings between the hydroxyl groups of cellulose and hydroxyl groups of CAB, carbonyl groups of carbamate esters and HEMA, and $\mathrm{NH}$ groups in carbamate esters are all responsible for the bonding mechanism.

Table 2. The tensile strength and peel test values of washed and UV-coated fabrics.

\begin{tabular}{|c|c|c|c|c|c|}
\hline & $\begin{array}{l}\text { Without } \\
\text { Washing } \\
\end{array}$ & ECE-Washed & $\begin{array}{l}\text { Alkaline- } \\
\text { Washed }\end{array}$ & $\begin{array}{c}\text { Enzymatic- } \\
\text { Washed }\end{array}$ & \\
\hline $\begin{array}{c}\text { Tensile } \\
\text { Strength (N) }\end{array}$ & 950 & 1001 & 1070 & 1080 & Uncoated \\
\hline Peel Test (N) & 16.3 & 20.2 & 23.6 & 27.8 & $\begin{array}{l}\text { Double } \\
\text { Layered UV- } \\
\text { Coated }\end{array}$ \\
\hline
\end{tabular}

\section{CONCLUSIONS}

In this study, the hydroxyl groups on CAB structure were modified by TDI-HEMA adduct in order to enhance the undesired properties of $C A B$ such as high viscosity due to the inelastic structure, low thermal stability etc. The obtained TDI-HEMA adduct and modified CAB oligomer were chemically characterized by FTIR and ${ }^{1} \mathrm{H}$ NMR spectroscopies. By using the modified CAB oligomer, UV-coating formulations were prepared and applied on doublelayered cotton fabrics. In order to increase the adhesion strength between UV-coating layer and cotton fabric surface, the ECE, alkaline, and enzymatic washing processes were applied on cotton fabrics prior to the UV-coating. All results are consistent that the washing step with pectinase enzyme showed the highest performance in the fibrillation of cotton fibers. Thus the highest absorbency and the least abrasion resistance by means of cycle were recorded in the case of enzymatic washed sample. After double-layered UVcoating process, the least abrasion resistance by means of weight loss percentage after 100 cycle and the highest peel strength were also recorded for enzymatic washed sample. Considering the industrial usage, a commercial tarpaulin fabric properties are as follows; flame resist, water-proof, and $850 \mathrm{~g} / \mathrm{m}^{2}$ in weight. The double-layered UVcoated fabric proposed in this paper is also waterproof, and having a lower weight of $524 \mathrm{~g} / \mathrm{m}^{2}$. Thus it can be suggested that the proposed UV-coated fabric can be used as light-weighted tarpaulin. Further studies are now in progress modifying the 
oligomeric structure by incorporation of phosphorus- containing flame resistant functional groups.

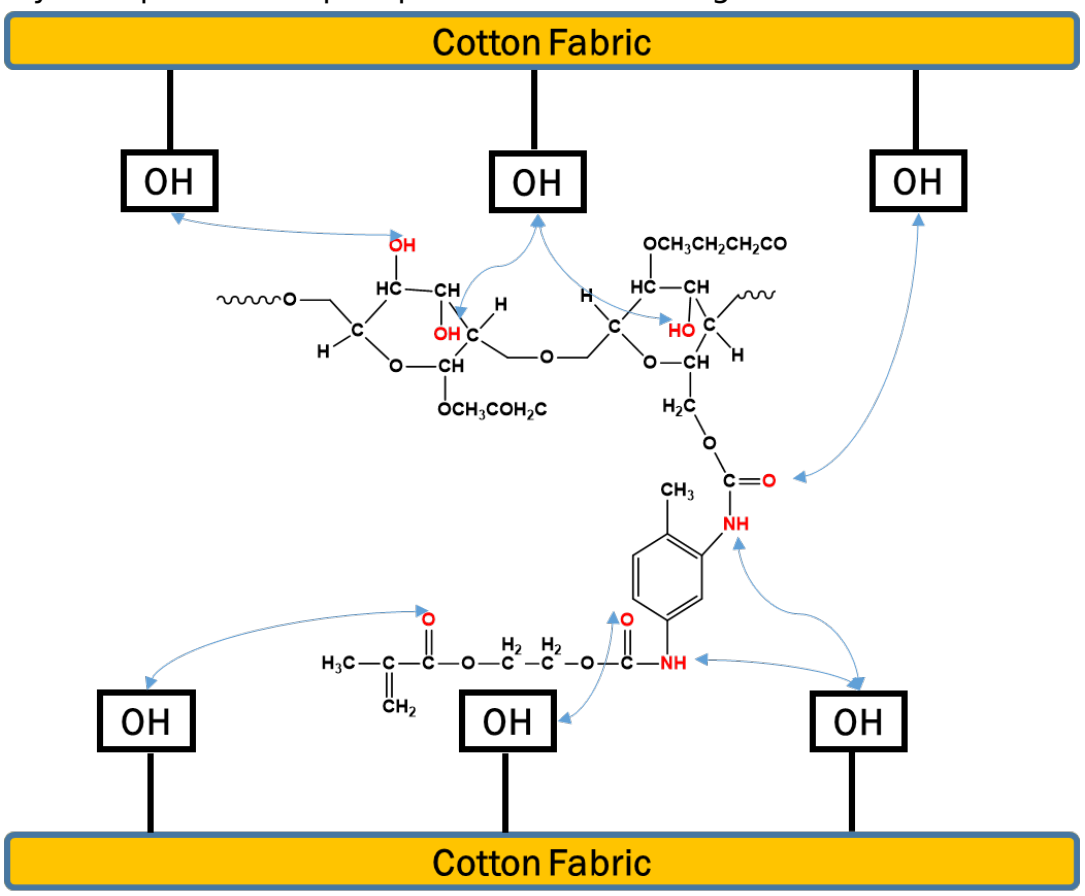

Figure 7. The bonding mechanism between the UV-coating layer and cotton fabric surface.

\section{ACKNOWLEDGEMENT}

The extended abstract of this study was orally presented in 31th National Chemistry Congress on 10-13 September 2019, Istanbul (31. Ulusal Kimya Kongresi 10-13 Eylül, 2019, Istanbul).

\section{REFERENCES}

1. Çakmakçı E, Güngör A, Kayaman-Apohan N, Kuruca SE, Çetin MB, Dar KA. Cell growth on in situ photo-cross-linked electrospun acrylated cellulose acetate butyrate. Journal of Biomaterials Science, Polymer Edition. 2012;23(7):887-99.

2. Wang $X$, Huang $S$, Wang $Y$, Wei $P$, Chen $Y$, Xia $Y$, et al. Eco-friendly cellulose acetate butyrate/poly (butylene succinate) blends: crystallization, miscibility, thermostability, rheological and mechanical properties. Journal of Polymer Research. 2017;24(2):16.

3. Biniaś W, Biniaś D. Formation of Microfibres from Cellulose Acetate Butyrate by Electrospinning with a Surface Modified in Low-temperature Plasma. Fibres \& Textiles in Eastern Europe. 2014.

4. Barszczewska-Rybarek IM. Characterization of urethane-dimethacrylate derivatives as alternative monomers for the restorative composite matrix. Dental Materials. 2014;30(12):1336-44.

5. Lei G, Angeli S, Kristol D, Snyder W. Preparation of new blocked diisocyanate for dental application. Journal of Polymer Science Part A: Polymer Chemistry. 1987;25(2):607-15.
6. Wang SJ, Wang YL, Yang PF, Li TD, editors. Preparation of polyurethane-poly (butyl acrylate) hybrid latexes via miniemulsion polymerization. Applied Mechanics and Materials; 2012: Trans Tech Publ.

7. Wang F, Hu J, Tu W. Study on microstructure of UVcurable polyurethane acrylate films. Progress in organic coatings. 2008;62(3):245-50.

8. Xie J, Zhang N, Guers M, Varadan VK. Ultravioletcurable polymers with chemically bonded carbon nanotubes for microelectromechanical system applications. Smart materials and structures. 2002;11(4):575.

9. Liu X-D, Sheng D-K, Gao X-M, Li T-B, Yang Y-M. UVassisted surface modification of PET fiber for adhesion improvement. Applied Surface Science. 2013;264:61-9.

10. Eker P. Farklı Hammaddeler iç̧eren Lycralı Dokuma Kumaşlarda Biyo-Parlatma ve BiyoParlatmanın Kumaş Performansına Etkileri. Adana 2012 (In Turkish).

11. Ozgen H. Farklı Yöntemlerle Pamuklu Örme Kumaşın Enzimatik Hidrofilleştirilmesi. Bartın 2018 (In Turkish).

12. Stanescu MD, Dochia M, Radu D, Sirghie C. Green solution for cotton scouring. Fibres \& Textiles in Eastern Europe. 2010;18(3):80.

13. SANCAR B, PAKSOY N, BALCI O, KURTOĞLU N. 
Pamuklu Dokuma Kumaşların Boyamaya Hazırlık İşlemlerinde Enzim Kullanım Olanaklarının İncelenmesi ve Kombine Proses Geliştirilmesi. Tekstil ve Mühendis. 2012;19(86) (In Turkish).

14. Toprak T. Pamuklu Kumaşlarda Kombine Enzim Proseslerinin Geliştirilmesi. Bursa 2014 (In Turkish).

15. Davulcu A. Pamuklu Kumaşların Ön Terbiye Proseslerinin Enzimatik Yöntemlerle Kombine Edilmesi Üzerine Bir Araştırma. Bursa 2008 (In Turkish).

16. Duran K, Bozacı E, Karahan H. Protein Esaslı Mamüllerin Enzimatik ÖnTerbiyesi. Tekstil ve Konfeksiyon. 2007;3:187-92.

17. Yılmaz B. Selülozik Materyallerin Tek Banyoda Kombine Proses ile Boyanmasında Optimizasyon. Istanbul 2004 (In Turkish).

18. Donelli I, Freddi G, Nierstrasz VA, Taddei P. Surface structure and properties of poly-(ethylene terephthalate) hydrolyzed by alkali and cutinase. Polymer Degradation and Stability. 2010;95(9):1542 50.

19. AATCC TM79-2018, Absorbency of Textiles. 2018.

20. TS EN ISO 13934-1:Tekstil - Kumaşların gerilme özellikleri - Bölüm 1:En büyük kuvvetin ve en büyük kuvvet altında boyca uzamanın şerit yöntemiyle tayini. 2013 (In Turkish).

21. TS EN ISO 5470-2:Lastik veya plastik kapl kumaşlar-Aşınma dayanımının tayini-Böllüm 2:Martindale aşındırıcı. 2004 (In Turkish).

22. TS EN ISO 12947-2:Tekstil - Martindale metoduyla kumaşların aşınmaya karşı dayanımının tayini- Bölüm 2: Numune kopmasının tayini. 2017 (In Turkish).

23. ASTM D1876-08: Standard Test Method for Peel Resistance of Adhesives (T-Peel Test). ASTM International: West Conshohocken, PA; 2015.

24. Grepinet $B$, Pla F, Hobbes $P$, Swaels $P$, Monge $T$. Modeling and simulation of urethane acrylates synthesis. I. Kinetics of uncatalyzed reaction of toluene diisocyanate with a monoalcohol. Journal of applied polymer science. 2000;75(5):705-12.

25. Liao $F$, Zeng X-r, Li H-q, Lai X-j, Zhao F-c. Synthesis and properties of UV curable polyurethane acrylates based on two different hydroxyethyl acrylates. Journal of Central South University. 2012;19(4):911-7.

26. Tan SZ, Wang Y, Zhang YF, Zhou WL, editors. Preparation of a novel prepolymer of polyurethane acrylate. Advanced Materials Research; 2012: Trans Tech Publ.

27. Dong Y, Edgar KJ. Imparting functional variety to cellulose ethers via olefin cross-metathesis. Polymer Chemistry. 2015;6(20):3816-27.

28. Dong $\mathrm{Y}$, Mosquera-Giraldo LI, Troutman J, Skogstad B, Taylor LS, Edgar KJ. Amphiphilic hydroxyalkyl cellulose derivatives for amorphous solid dispersion prepared by olefin cross-metathesis. Polymer Chemistry. 2016;7(30):4953-63.

29. Kunwong D, Sumanochitraporn N, Kaewpirom S. Curing behavior of a UV-curable coating based on urethane acrylate oligomer: the influence of reactive monomers. Sonklanakarin Journal of Science and Technology. 2011;33(2):201. 